\title{
Decreased numerical density of kainate receptor-positive neurons in the orbitofrontal cortex of chronic schizophrenics
}

Received: 8 December 2005 / Accepted: 1 February 2006/Published online: 28 February 2006

(C) Springer-Verlag 2006

\begin{abstract}
We utilised postmortem brain tissue to quantify sections of left and right orbitofrontal cortex (area 11) from nine schizophrenic and eight control patients from the Charing Cross Prospective Schizophrenia Study immunostained for the presence of the kainate receptor (GluR5/6/7). The numerical density of neurons immunopositive for kainate receptor was measured. Other sections from the same blocks were stained with cresyl violet to determine the total neuronal numerical density. All measurements were made blind: diagnoses were only revealed by a third party after measurements were completed. There was a significant reduction $(21 \%)$ in numerical density of kainate receptor-positive neurons in both cortices in the schizophrenic group (488 cells $/ \mathrm{mm}^{2}$ ) compared to that in the control group (618 cells $/ \mathrm{mm}^{2}$ ) $(P=0.033)$. Nissl-stained tissue showed no significant difference in total neuronal numerical density between control and schizophrenic groups. These observations suggest that there are actually fewer kainate receptorpositive neurons in schizophrenic orbitofrontal cortex. There was no correlation of reduced kainate receptorpositive cell number with age at death, postmortem interval, or other possibly confounding neuropathology. Our results support the concept of there being reduced glutamatergic activity in frontal cortex in schizophrenia.
\end{abstract}

\footnotetext{
L. J. Garey $(\square)$

Centre for Psychiatric Neuroscience, University of Lausanne, 1008, Lausanne, Switzerland

E-mail: 1.garey@freesurf.ch

Tel.: + 41-21-8253115

Fax: $+41-21-8253115$
}

Present address: L. J. Garey

Route Suisse 43, 1166, Perroy, Switzerland

K. A. Von Bussmann

Marshall House Surgery, SG5 1LH, Hitchin, UK

\section{S. R. Hirsch}

Division of Neuroscience and Psychological Medicine, Imperial College Faculty of Medicine, W6 8RF, London, UK
Keywords Postmortem - Cerebral cortex - Glutamate receptors $\cdot$ Kainate $\cdot$ Schizophrenia

\section{Introduction}

Since the observation that the cerebrospinal fluid of schizophrenics contained less glutamate than that of controls (Kim et al. 1980), there has been increasing evidence that glutamate receptors play a role in schizophrenia (Deutsch et al. 1988; Hirsch et al. 1997). Phencyclidine (PCP) and amantidine, both glutamate $N$-methyl-D-aspartate (NMDA) receptor antagonists, can elicit a psychotic state resembling schizophrenia, which includes negative as well as positive symptoms (Luby et al. 1959; Zukin and Zukin 1979; Lodge et al. 1987; Javitt and Zukin 1991; Meltzer 1991; Kornhuber et al. 1993).

The kainate subtype of glutamate receptor has been shown to colocalise with other subtypes in prefrontal cortical neurons in monkeys (Vickers et al. 1993). Although increases in glutamate receptor binding (including kainate receptors) have been reported in postmortem samples from the prefrontal cortex of schizophrenics (Nishikawa et al. 1983; Toru et al. 1988; Deakin et al. 1989), kainate receptors are down-regulated in the neocortex and hippocampus in schizophrenia (Kerwin et al. 1990; Harrison et al. 1991; Porter et al. 1997; Sokolov 1998). It has also been shown that in schizophrenics glutamatergic cortical pyramidal neurons have fewer than normal dendritic spines, on which glutamate receptors are concentrated (Garey et al. 1998; Glantz and Lewis 2000).

The prefrontal cortex is hypoactive in schizophrenia (Rubin et al. 1994). Its regional cerebral blood flow is decreased in schizophrenics performing various neuropsychological tests (Weinberger et al. 1986; Satoh et al. 1993). In particular, the orbitofrontal cortex (area 11 of Brodmann 2005) has been implicated with affective behaviour and integration of emotional responses in monkey and man (Lewin 1960; Gray 1981; Grafman et al. 1986). 
We therefore decided to compare the numerical density of neurons stained by an immunocytochemical method for kainate receptor in the orbitofrontal cortex of a series of schizophrenic and control postmortem specimens. We tested the hypothesis that kainate receptor-positive cells are reduced in schizophrenia, and examined whether this was independent of total cell count, determined from Nissl-stained sections, and other important variables such as age and postmortem interval (PMI).

\section{Methods}

\section{Specimens and fixation}

Samples from the orbitofrontal cortex (area 11) of nine schizophrenic (five males, four females) and eight control patients (three males, five females) were used (Tables 1, 2) from the Charing Cross Prospective Schizophrenia Study, as approved by the Charing Cross Hospital Ethics Committee. The average age of the controls was 64 years (range 27-81), and of the schizophrenics was 75 (range 46-86). The mean PMI (the delay from death to fixation of tissue) was $28 \mathrm{~h}$ for the controls and $14 \mathrm{~h}$ for the schizophrenics. The diagnosis of schizophrenia was made using DSM-IIIR criteria, but was only revealed to the experimenters by a third party after the completion of all measurements. Gross pathological abnormalities were excluded by visual inspection of the whole brain and coronal slices at the time of autopsy. Particular attention was paid to the substantia nigra and the caudate nucleus (for Parkinson and Huntington disease, respectively).

After removal from the skull, each brain was dissected according to a standardised protocol. For the present study, blocks from the left and right area 11 were immersed in $4 \%$ buffered paraformaldehyde for fixation before being embedded in paraffin wax, sectioned at $10 \mu \mathrm{m}$, and mounted on glass slides coated with chromealum gelatin.

\section{Kainate receptor immunostaining}

Four sections from each block were immunostained with a mouse monoclonal antibody recognising the kainate receptor subunit GluR5/6/7 in mouse, monkey and man (Chemicon) previously described as labelling specific neurons in primate neocortex (Huntley et al. 1993). After dewaxing, the slides were soaked in $0.3 \%$ hydrogen peroxide in phosphate-buffered saline for $30 \mathrm{~min}$ to block any endogenous peroxidase reactions, and microwaved in citrate buffer $(\mathrm{pH} 6)$ for 5 min to enhance the presentation of the antigen (Newman and Gentleman 1997). The slides were then immersed in a blocking solution (Vector Laboratories SP-2001) to block endogenous avidin and biotin, before incubating overnight in the kainate receptor antibody diluted 1:200. A standard ABC (Vectastain) routine was then used, and the staining visualised using a metal-enhanced diaminobenzidine substrate in stabilised peroxide buffer solution (Pierce Chemical), with subsequent treatment in $0.01 \%$ osmium tetroxide solution. The sections were dehydrated and covered, and then quantified. Kainate receptor-positive cells in a column from the pia to the white matter were counted at $\times 200$ independently by two observers using a microscope with a calibrated $10 \times 10$ graticule. The cells that were counted were all judged to be neurons using criteria of their relatively large size, their shape, staining density and high cytoplasm to nucleus ratio. The occasional immunopositive glial cells were not counted (see Results). For each brain, the mean value of the two observers' counts of cells per $\mathrm{mm}^{2}$ was calculated. Differences between the schizophrenic and control brains were tested for significance by using the non-parametric Mann-Whitney test. Two-tailed statistics were used. The Mann-Whitney test was chosen because the left-sided total cell counts were skewed in both diagnostic groups, as were the right-sided values in the schizophrenic group, and the PMIs. Only neurons that were sectioned through their nucleus were counted, but we elected not to use formal stereological methodology. Although this may have reduced the absolute

Table 1 Details of the control brains used in this study

\begin{tabular}{|c|c|c|c|c|c|c|c|c|c|c|}
\hline Case number & Sex & Age & PMI & Kainate L & Kainate $\mathrm{R}$ & Nissl L & Nissl R & Cause of death & Plaques & Tangles \\
\hline 16 & $\mathrm{~F}$ & 67 & 1 & 443 & 477 & 1,027 & 1,077 & $\mathrm{PE}$ & & \\
\hline 27 & $\mathrm{~F}$ & 79 & 29 & 688 & 631 & 1,265 & 1,226 & Peritonitis & & \\
\hline 28 & M & 57 & 22 & 487 & 546 & 935 & 932 & $\mathrm{PE}$ & & \\
\hline 29 & M & 54 & 29 & 637 & 578 & 908 & 993 & Renal failure & & \\
\hline 30 & $\mathrm{~F}$ & 27 & 27 & 572 & 536 & 896 & 715 & Hepatic failure & & \\
\hline 31 & $\mathrm{~F}$ & 81 & 80 & 784 & 731 & 881 & 1,341 & GI haemorrhage & & \\
\hline 35 & $\mathrm{M}$ & 67 & 18 & 518 & 480 & 978 & 1,054 & Septicaemia & & \\
\hline 89 & $\mathrm{~F}$ & 79 & 16 & 874 & 903 & 1,171 & 1,178 & MI & ++ & - \\
\hline Mean & & 64 & 28 & 625 & 610 & 1,008 & 1,065 & & & \\
\hline Mean $L+R$ & & & & 618 & & 1,036 & & & & \\
\hline SD & & & & 142.6 & & 165.6 & & & & \\
\hline
\end{tabular}

Each column of results refers to the numerical density of neurons per $\mathrm{mm}^{2}$ in kainate receptor immunostained or Nissl-stained sections from the left (L) or right (R) cortex. The two bottom lines refer to the means and standard deviations of results from both sides $P M I$ postmortem interval in hours (from death to fixation of tissue), $P E$ pulmonary embolism, $G I$ gastrointestinal, $M I$ myocardial infarction 
Table 2 Details of the schizophrenic brains used in this study

\begin{tabular}{|c|c|c|c|c|c|c|c|c|c|c|}
\hline Case number & Sex & Age & PMI & Kainate L & Kainate $\mathrm{R}$ & Nissl L & Nissl R & Cause of death & Plaques & Tangles \\
\hline 12 & M & 65 & 72 & 457 & 443 & 1,131 & 1,026 & Bronchopneumonia & - & + \\
\hline 21 & M & 82 & 5 & 587 & 585 & 991 & 892 & Bronchopneumonia & & \\
\hline 39 & $\mathrm{M}$ & 80 & 4 & 429 & 462 & 1,317 & 1,349 & & & \\
\hline 84 & $\mathrm{~F}$ & 46 & 23 & 470 & 523 & 1,056 & 958 & Hanging & - & - \\
\hline 85 & $\mathrm{~F}$ & 82 & 8 & 431 & 438 & 1,404 & 1,435 & Bronchopneumonia & - & - \\
\hline 86 & M & 77 & 3 & 445 & 474 & 1,116 & 1,166 & Bronchopneumonia & +++ & ++ \\
\hline 87 & M & 79 & 5 & 531 & 491 & 1,232 & 1,213 & $\mathrm{Ca}$ bronchus & + & - \\
\hline 88 & $\mathrm{~F}$ & 75 & 3 & 481 & 491 & 885 & 781 & Ca bladder & + & - \\
\hline 90 & $\mathrm{~F}$ & 86 & 5 & 515 & 539 & 1,309 & 1,175 & Ca gall bladder & ++ & + \\
\hline Mean & & 75 & 14 & 483 & 494 & 1,160 & 1,111 & & & \\
\hline Mean $\mathrm{L}+\mathrm{R}$ & & & & 488 & & 1,135 & & & & \\
\hline SD & & & & 49.1 & & 189 & & & & \\
\hline
\end{tabular}

Layout and conventions as for Table 1

Ca carcinoma

reliability of our results, we consider that the technique described above gives an acceptable degree of confidence in comparing individual cases across the cohorts.

\section{Nissl staining}

Of the remaining sections from each block, two were stained with cresyl violet for Nissl substance to determine total cell numerical density. Cells were counted in these Nissl-stained sections using a SeeScan image analysis system. Two columns from the pia to the white matter were chosen and all cells with a diameter greater than $8 \mu \mathrm{m}$ counted. It was assumed that smaller cells would be mainly, if not all, glia. Again, the results were expressed as cells per $\mathrm{mm}^{2}$.

Two other sections were stained for glial fibrillary acidic protein (GFAP) to identify astrocytes.

Seven of the schizophrenic brains and one control were subjected to a modified CERAD examination (Mirra et al. 1991). Blocks from frontal, temporal, parietal, occipital and cingulate cortex were stained with IE8 antibody for plaques and AT8 for tangles (Tables 1, 2). Material was not available for this from the other cases.

\section{Results}

\section{Histology}

Cells labelled for kainate receptor were visible in all cortical layers. The most clearly labelled cells were large and small pyramidal neurons, especially in layers III and V. Their soma had a large volume of light cytoplasm compared with the nuclear size, and apical and basal dendrites were easily visible. Medium to small non-pyramidal cells, again with large volumes of light cytoplasm, were also stained, mainly in layers II and IV. Almost all immunopostive cells were judged to be neurons, in that none were very small, and they had the morphological characteristics of neurons (see above). A few kainate receptor-positive cells were identified as astrocytes by their typical morphology (small soma with multiple, fibrous ramifications). Bundles of axons were also labelled, both in the white matter and fanning out into the deep layers of grey matter, especially near the apex of gyri (Fig. 1).

\section{Results from Nissl-stained sections}

Results (Tables 1, 2 and Fig. 2) from Nissl-stained sections showed that the total numerical density of neurons in the left and right cortices of the schizophrenic group $\left(1,160\right.$ and 1,111 cells $\left./ \mathrm{mm}^{2}\right)$ was not significantly different from that in the left and right cortices of the control group $(1,008$ and 1,065), but approached significance for the left cortex $(P=0.063, t=2.006)$. Mean values were therefore calculated for both sides $(1,135$ and 1,036), again revealing no significant difference (Table 1). However, although not reaching significance, in each case (left cortices, right cortices and both cortices combined) there was a consistent, slightly higher numerical density of neurons in the schizophrenic brains of $13 \%$ between left cortices, $4 \%$ between right cortices, and $9 \%$ overall between schizophrenics and controls.

\section{Kainate receptor-positive cells}

Results from kainate receptor-immunostained tissue revealed no significant difference in the number of immunopositive neurons between left and right sides of control or schizophrenic brains. However, there were significantly fewer kainate receptor-positive neurons in the schizophrenics than the controls, when the left orbitofrontal cortex of the schizophrenic group (483 cells/ $\mathrm{mm}^{2}$ ) was compared to the left cortex of the control group $\left(625 \mathrm{cells} / \mathrm{mm}^{2}\right)$, i.e. a $23 \%$ reduction $(P=0.033)$. A comparison of the right orbitofrontal cortex of the schizophrenic group (494 cells $\left./ \mathrm{mm}^{2}\right)$ with that of the right cortex of the control group $\left(610\right.$ cells $\left./ \mathrm{mm}^{2}\right)$ showed a non-significant $(19 \%)$ reduction $(P=0.060)$. When 
Fig. 1 Micrograph of a section from orbitofrontal cortex of a schizophrenic, labelled for kainate receptor. Note the staining of pyramidal and nonpyramidal cell bodies, and of neuropil profiles, especially dendrites

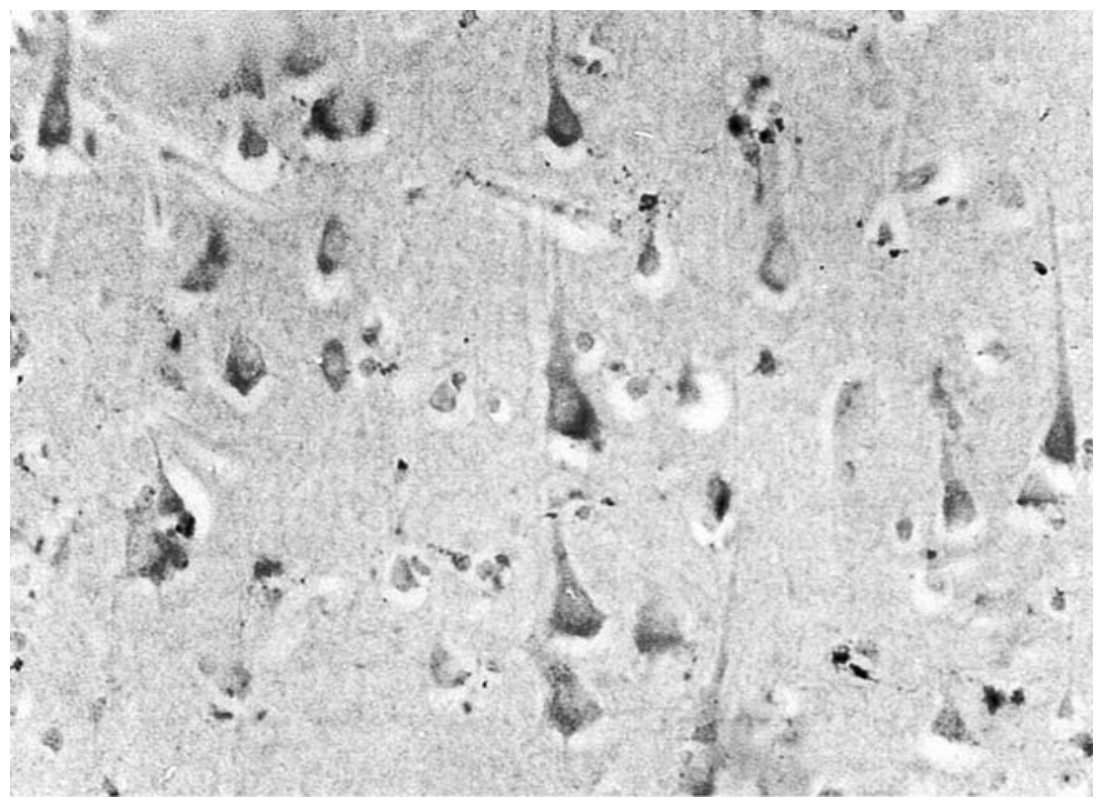

both the left and right cortex of the schizophrenic group were combined and compared to those in the control brains, the lower numerical density of stained neurons in

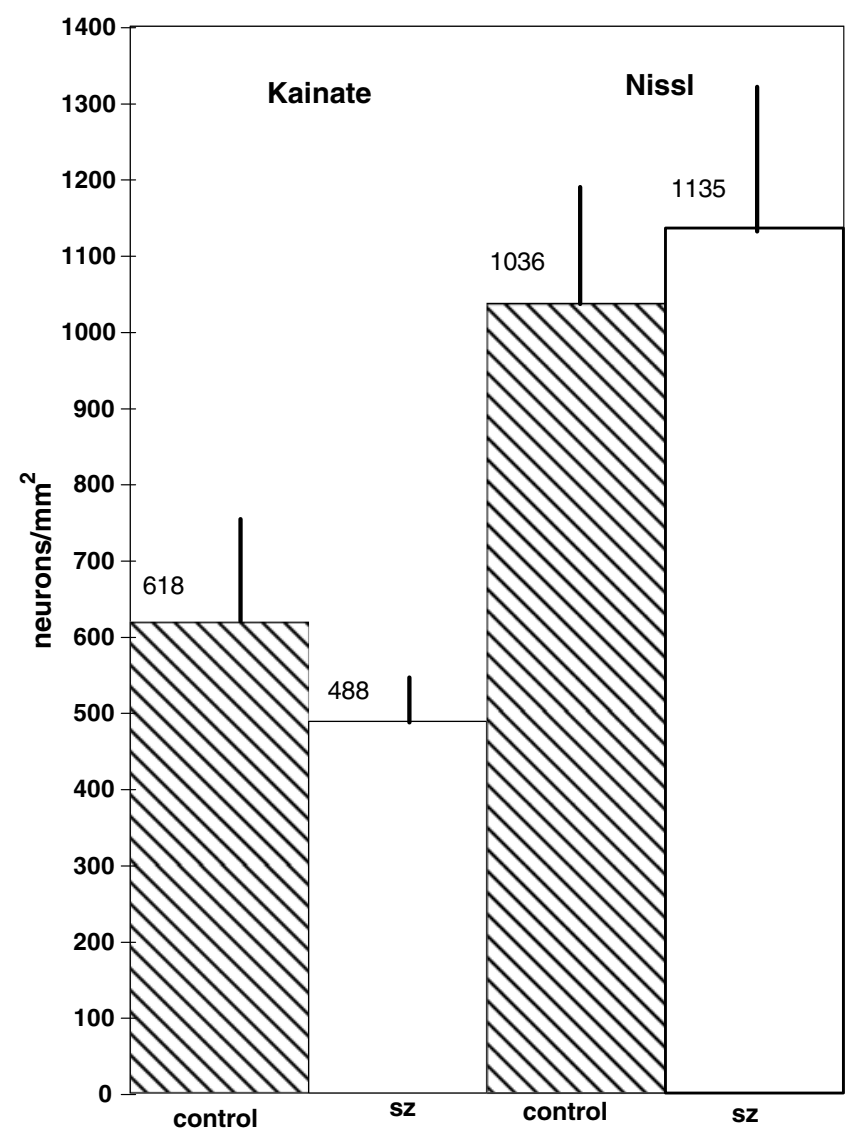

Fig. 2 Histograms to show the numerical density of neurons (showing mean values $\pm \mathrm{SD}$ ) stained for kainate receptor and Nissl substance, respectively in control and schizophrenic $(s z)$ brains. There is a significant $(P=0.001)$ reduction in kainate receptorpositive neuronal density, and a consistent but non-significant increase in total neuronal density, in schizophrenic cortex the schizophrenic group was highly significant (488 compared with $618 ; 21 \%$ reduction; $P=0.001$ ) (Table 1 ).

Of the nine schizophrenic brains, material was available from seven to study for the presence of plaques and tangles indicative of possible Alzheimer disease. Only one (number 86) showed signs of moderate to heavy involvement, and one other (number 90) light to moderate.

\section{Discussion}

In human orbitofrontal cortex, we found kainate receptor-positive neurons in all cortical layers in both control and schizophrenic tissue. Pyramidal and nonpyramidal cells were labelled, and staining was seen not only in somata and dendrites, but also in axons in the white and grey matter (Vickers et al. 1995). The fact that GluR staining is not confined to the cortical neuropil (where it stains asymmetrical postsynaptic densities), but marks neuronal cell bodies, is revealed by our own and others' light and electron microscopic studies in rat (Petralia and Wenthold 1992; Petralia et al. 1994; Ong and Gorey 1996), monkey (Huntley et al. 1993) and man (Ong and Garey 1996). In our present material, some cells with typical features of astrocytes were stained for kainate receptor. We compared the sections stained for GFAP (see Methods) to confirm this diagnosis. There was no suggestion in any of the sections examined of actual gliosis. Glia have been reported to stain for kainate in human cortex from epileptic and other pathological cases (DeFelipe et al. 1994; Vickers et al. 1995).

Although we did not use formal stereological methodology for quantification, as described in Methods, we believe that our counting technique gave an acceptable level of reliability. We found a significant decrease of $21 \%$ in the numerical density of neurons stained for kainate receptor in schizophrenic cortex compared to 
the control group. In contrast, the counts of Nisslstained neurons were not significantly different between controls and schizophrenics, although there was a consistent trend toward a small increase in neuronal numerical density in the schizophrenic cortex. Previous literature suggests a decrease in the thickness of the cortex in schizophrenics compared to normal controls (Selemon et al. 1995). This could cause an increase in the numerical density of neurons, without a decrease in their total number in the cortex. As the total numerical density of neurons in the cortex thus does not change significantly, but may even be slightly increased, the finding of fewer neurons per unit area expressing the kainate receptor in schizophrenics suggests a real loss of neurons labelled for kainate receptor. It is of interest that Benes et al. (2001) described a decrease of some $30 \%$ in the number of apical dendrites immunoreactive for GluR5/6/7 on pyramidal neurons in the stratum radiatum of the hippocampus in schizophrenic brains.

Our findings are, however, in contrast to the work showing an increase in kainate binding in frontal cortex of schizophrenics (Nishikawa et al. 1983; Deakin et al. 1989). However, this previous work was done with brain homogenates and is not directly comparable to the quantification of receptor-positive neurons in the present work.

There are several confounding factors that must be considered in our study. The first is that of age. The mean age of the schizophrenics was higher than that of the controls (75 years compared to 64). Figure 3 illustrates scatter plots of all the results of this study with linear regression lines added. There is a slight tendency for increased neuronal density with age, both for Nissl results (total neurons), as described earlier (Leuba and Garey 1987), and for kainate receptor-positive cells. However, this trend cannot explain the low neuronal density in the schizophrenics. Indeed, if the control aged 27 (outside the age range of the schizophrenics) is excluded, the reduction in the density of kainate receptor-positive cells is slightly greater $(22 \%)$.

None of our schizophrenic patients had clinical Alzheimer disease, as determined from their hospital notes, and no sign of it macroscopically at autopsy. Modified CERAD (Mirra et al. 1991) staining for plaques and tangles revealed possible (subclinical) Alzheimer pathology in two brains. Neither showed particularly low neuronal counts, either for total cells or kainate receptor. If Alzheimer disease had existed in any of our controls, it would be expected to act against the hypothesis that loss of kainate receptor-positive cells in schizophrenia might be induced by this (or other) pathology. We interpret these results as suggestive of Alzheimer disease not being a confounding factor in our study. Interestingly, case 21 was reported clinically as having non-Alzheimer type dementia, and had the highest number of kainate receptor-positive neurons in this series.

One of our controls (case 16) had been diagnosed with an atypical psychosis 2 years before death. As there was no history of schizophrenia as such, we maintained this case in the control group. It is worth noting that if she had been excluded, the mean count for kainate receptor-positive neurons in the controls would have been even higher $\left(640 / \mathrm{mm}^{2}\right.$, rather than 618$)$, without a significant change in total neuronal density.

It is possible that treatment of our schizophrenic patients with neuroleptics could influence receptors. They may have variable, and even toxic effects in animals (Sommer and Quandt 1970; Eastwood et al. 1994, 1996; Healy and Meador-Woodruff 1997). However, Benes et al. (1985) found no correlation between neuroleptic treatment and total neuronal density in a comparison of schizophrenics and controls, and others have suggested that such therapy probably does not affect glutamate receptors (Eastwood et al. 1994; Oretti et al. 1994). Sokolov (1998) demonstrated that levels of glutamate receptor mRNA in schizophrenics receiving neuroleptics up to death did not differ from those in controls, but actually declined after cessation of neuroleptic therapy.

The effect of an altered social environment must also be considered. The schizophrenics had spent long periods in institutions, compared with controls from comparatively rich social environments. The effects of social deprivation in humans are unknown, and new material is now being collected from institutionalised non-schizophrenics and younger, non-chronic schizophrenics.

Postmortem delay could result in tissue damage, and this might lead to loss of immunoreactivity. However, in our cases the mean PMI was twice as long for the control cases, thus acting against that hypothesis. Furthermore, we found no consistent relationship between PMI and kainate receptor staining. The shortest PMI was in case 16, where the count of immunopositive cells was below average. The case with the longest delay (number 31) had a high count.

The present finding of a decreased numerical density of neurons labelled for kainate receptor in the orbitofrontal cortex of schizophrenic patients is consistent with glutamate receptor hypofunction, or dysfunction. Down-regulation of glutamate receptor activity has been widely implicated in schizophrenia (Deutsch et al. 1988; Kerwin et al. 1990; Harrison et al. 1991; Sherman et al. 1991; Squires and Saederup 1991; Lieberman and Koreen 1993; Humphries et al. 1996; Porter et al. 1997; Sokolov 1998). A combined dysfunction of dopamine and glutamate receptors has also been proposed (Olney and Farber 1995). Glutamate receptors are present on the dendrites and spines of cortical neurons, including pyramidal cells (Petralia et al. 1994; He et al. 1996; Ong and Garey 1996) which are heavily stained for kainate receptor in the present study. Since pyramidal neurons are intercortical association cells, it is possible that communication between neocortical areas may be disrupted as a result of loss of glutamate receptors. Prefrontal cortex is strongly connected to other association cortex and the limbic system. Lesions of the frontal lobe affect higher cognitive function (Gold et al. 1992). Thus, 
Fig. 3 Linear regression curves to test the effect of age on neuronal density in control (a) vand schizophrenic (b) brains. Nissl results for each side of each brain are indicated by triangles and kainate results by squares. In some cases the values overlap. There is a slight tendency for increased neuronal density with age, more marked for the Nissl results
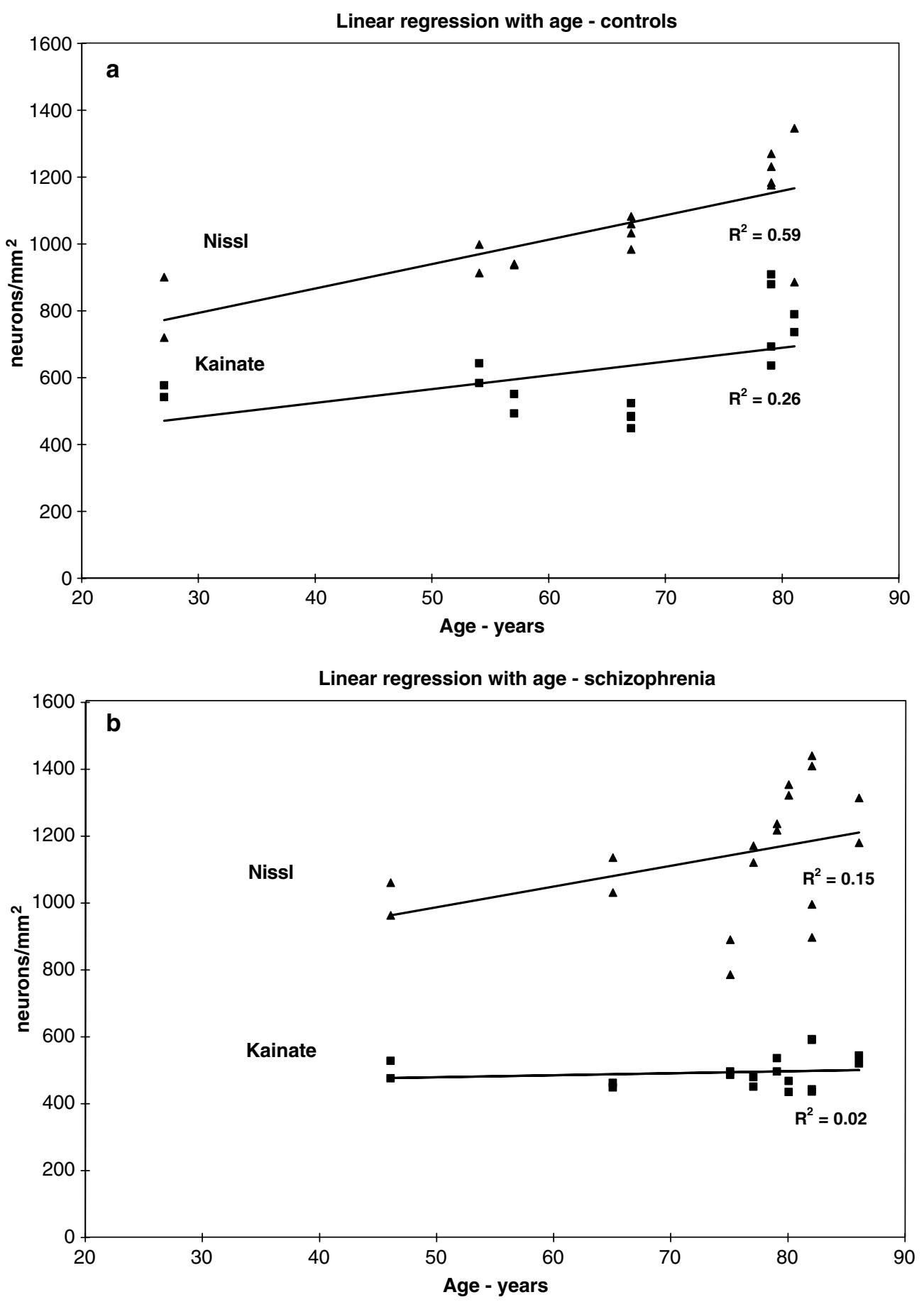

down-regulation of kainate receptor activity or connectivity in frontal cortex could disturb complex integrative functions, leading to changes in higher cognitive activity such as seen in schizophrenia.

Electron microscopy of schizophrenic cortex has shown abnormal excitatory synapses with vesicles that clump away from unusually short postsynaptic densities where glutamate receptor is situated (Ong and Garey 1993). Excessive pruning of prefrontal synapses, perhaps involving excitatory glutamatergic input to pyramidal neurons, is a possible aetiological factor in schizophre- nia (Keshavan et al. 1994). Observations of reduced numbers of pyramidal dendritic spines in schizophrenia (Garey et al. 1998; Glantz and Lewis 2000), may be related to the concept of disturbed elimination of connections in the neuropil, including that of exuberant connections that are a normal part of development (Innocenti and Price 2005).

In addition, excitatory glutamatergic activity at synapses, including at kainate receptors, is linked to the normal development of neurons (Henley 1994), and their connections (Shatz 1990). NMDA receptors are also 
involved in the detection of coincidental pre- and postsynaptic activity at excitatory synapses, linked to increase in synaptic efficacy, memory formation and learning (Morris et al. 1986; Bliss and Collingridge 1993). Disturbance of any of these factors could be of importance in the pathogenesis of schizophrenia. It remains, however, to determine whether the decrease in kainate receptors is a cause or a consequence of neuronal pruning in schizophrenia.

The present results, taken in conjunction with evidence of reduced GABAergic neuronal activity as judged by gene expression deficits in neurons positive for GABA enzymes or calcium-binding proteins without actual loss of neurons themselves (Akbarian et al. 1995, Leclercq et al. 1996, Leuba et al. 1997, Reynolds and Beasley 2001, Hashimoto et al. 2003), provide support for the concept that schizophrenia may be a disease of microcircuitry in the neuropil rather than of neuronal number (Selemon and Goldman-Rakic 1999). Further, our observation that the numerical density of microglia is significantly higher in schizophrenia than in controls, may also point to possible precocious alterations in neuropil architecture in schizophrenia (Radewicz et al. 2000).

There have been suggestions that schizophrenia may be related to abnormal hemispheric asymmetry or lateralisation (Crow et al. 1989). However, we find no evidence of significant hemispheric differences in the phenomena that we describe here, although we examined both hemispheres, and the same applies to our previous results (Radewicz et al. 2000). It should also be emphasised that the pathological changes identified in schizophrenia to date are not restricted to a specific area of cortex, although most have related to hippocampus or association neocortex. For example, we have demonstrated changes, described above, in frontal, temporal and cingulate cortex (Garey et al. 1998; Radewicz et al. 2000).

It would now be of interest to follow up the present studies by quantifying the density of kainate receptor labelling in the neuropil (essentially dendritic and axonal marking) in controls and schizophrenics, especially as we have noted decreased GABAergic labelling in schizophrenic neuropil without decreased numerical density of somata (Leuba et al. 1997).

This work was supported by grants from the Stanley Foundation (European Research Center). A. D. Rodway was responsible for preliminary studies. Control brains were provided by C. Hornstein and M. Bauer. We are grateful to S. M. Gentleman for screening for Alzheimer disease and to T. B. Bull for expert technical assistance. We thank F. Benes and W. Y. Ong for invaluable comments on the manuscript.

\section{References}

Akbarian S, Kim JJ, Potkin SG, Hagman JO, Tafozzoli A, Bunney WE, Jones EG (1995) Gene expression for glutamic acid decarboxylase is reduced without loss of neurons in prefrontal cortex of schizophrenics. Arch Gen Psychiatry 52:258-266
Benes FM, Paskevich PA, Davidson J, Domesick VB (1985) Synaptic rearrangements in medial prefrontal cortex of haloperidoltreated rats. Brain Res 348:15-20

Benes FM, Todtenkopf MS, Kostoulakos P (2001) GluR5,6,7 subunit immunoreactivity on apical pyramidal cell dendrites in hippocampus of schizophrenics and manic depressives. Hippocampus 11:482-491

Bliss TVP, Collingridge GL. (1993) A synaptic model of memory: long-term potentiation in the hippocampus. Nature 361:31-39

Brodmann K (2005) Vergleichende Lokalisationslehre der Grosshirnrinde in ihren Prinzipien dargestellt auf Grund des Zellenbaues. Leipzig: Barth, 1909. Translated by LJ Garey as: Brodmann's Localisation in the Cerebal Cortex London: Smith-Gordon, 1994. 3rd edn Springer, Berlin, Heidelberg, New York

Crow TJ, Ball J, Bloom SR Brown R, Bruton CJ, Colter N, Frith CD, Johnstone EC, Owens DG, Roberts GW (1989) Schizophrenia as an anomaly of development of cerebral asymmetry. A postmortem study and a proposal concerning the genetic basis of the disease. Arch Gen Psychiatry 46:1145-1150

Deakin JFW, Slater P, Simpson MDC, Gilchrist AC, Skan WJ, Royston MC, Reynolds GP, Cross AJ (1989) Frontal cortical and left temporal glutamatergic dysfunction in schizophrenia. J Neurochem 52:1781-1786

DeFelipe J, Huntley GW, Del Rio MR, Sola RG, Morrison JH (1994) Microzonal decreases in the immunostaining for nonNMDA ionotropic excitatory amino acid receptor subunits GluR2/3 and GluR5/6/7 in the human epileptogenic cortex. Brain Res 657:150-158

Deutsch SI, Mastropaolo J, Schwartz BL, Rosse RB, Morihisa JM (1988) A "glutamatergic hypothesis" of schizophrenia. Rationale for pharmacotherapy with glycine. Clin Neuropharmacol $12: 1-13$

Eastwood SL, Story P, Burnet PWJ, Heath P, Harrison PJ (1994) Differential changes in glutamate receptor subunit mesenger RNAs in rat brain after haloperidol treatment. J Psychopharmacol 8:196-203

Eastwood SL, Porter RH, Harrison PJ (1996) The effect of chronic haloperidol treatment on glutamate receptor subunit (GluR1, GluR2, KA1, KA2, NR1) mRNAs and glutamate binding protein mRNA in rat forebrain. Neurosci Lett 212:163-166

Garey LJ, Ong WY, Patel TS, Kanani M, Davis A, Mortimer AM, Barnes TRE, Hirsch SR (1998) Reduced dendritic spine density on cerebral cortical pyramidal neurons in schizophrenia. J Neurol Neurosurg Psychiatry 65:446-453

Glantz LA, Lewis DA (2000) Decreased dendritic spine density on prefrontal cortical pyramidal neurons in schizophrenia. Arch Gen Psychiatry 57:65-73

Gold JM, Goldberg TE, Weinberger DR (1992) Prefrontal function and schizophrenic symptoms. Neuropsychiatry Neuropsychol Behav Neurol 5:253-261

Grafman J, Vance SC, Weingartner H, Salazar AM, Amin D (1986) The effects of lateralized frontal lesions on mood regulation. Brain 109:1127-1148

Gray JA (1981) Anxiety as a paradigm case of emotion. Brit Med Bull 37:193-197

Harrison PJ, McLaughlin D, Kerwin RW (1991) Decreased hippocampal expression of a glutamate receptor gene in schizophrenia. Lancet 337:450-452

He Y, Ong WY, Leong SK, Garey LJ (1996) Distribution of glutamate receptor subunit GluR1 and GABA in human cerebral neocortex: a double labelling and electron microscopic study. Exp Brain Res 112:147-157

Healy DJ, Meador-Woodruff JH (1997) Clozapine and haloperidol differentially affect AMPA and kainate receptor subunit mRNA levels in rat cortex and striatum. Molec Brain Res 47:331-338

Henley JM (1994) Kainate-binding proteins: phylogeny, structures and possible functions. Trends Pharmacol Sci 15:182-190

Hirsch SR, Das I, Garey LJ, de Belleroche J (1997) A pivotal role for glutamate in the pathogenesis of schizophrenia, and its cognitive dysfunction. Pharmacol Biochem Behav 56:797-802 
Humphries C, Mortimer A, Hirsch S, de Belleroche J (1996) NMDA receptor mRNA correlation with antemortem cognitive impairment in schizophrenia. NeuroReport 7:2051-2055

Huntley GW, Rogers SW, Moran T, Janssen W, Archin N, Vickers JC, Cauley K, Heinemann SF, Morrison JH (1993) Selective distribution of kainate receptor subunit immunoreactivity in monkey neocortex revealed by a monoclonal antibody that recognizes glutamate receptor subunits GluR5/6/7. J Neurosci 13:2965-2981

Innocenti GM, Price DJ (2005) Exuberance in the development of cortical networks. Nature Rev Neurosci 6:955-965

Javitt DC, Zukin SR (1991) Recent advances in the phencyclidine model of schizophrenia. Am J Psychiatry 148:1301-1308

Kerwin RW, Patel S, Meldrum B (1990) Quantitative autoradiographic analysis of glutamate binding sites in the hippocampal formation in normal and schizophrenic brain post mortem. Neurosci 39:25-32

Keshavan MS, Anderson S, Pettegrew JW (1994) Is schizophrenia due to excessive synaptic pruning in the prefrontal cortex? The Feinberg hypothesis revisited. J Psychiatry Res 28:239-265

Kim JS, Kornhuber HH, Schmid-Burgk W, Holzmuller B (1980) Low cerebrospinal fluid glutamate in schizophrenic patients and a new hypothesis on schizophrenia. Neurosci Lett 20:379-382

Kornhuber J, Weller M, Riederer P (1993) Glutamate receptor antagonists for neuroleptic malignant syndrome and akinetic hyperthermic Parkinsonian crisis. J Neural Transm 6:63-72

Leclercq P, Royston MC, Garey LJ, Gentleman SM (1996) A positional analysis of a subset of cortical neurons in the frontal cortex of schizophrenic brains. Neuropathol Appl Neurobiol $22: 164$

Leuba G, Garey LJ (1987) Evolution of neuronal numerical density in the developing and aging human visual cortex. Hum Neurobiol 6:11-18

Leuba G, Saini K, Baeryswil F, Kraftsik R, Garey LJ (1997) Qualitative distribution of calcium-binding proteins in frontal and temporal cortex of control and schizophrenic brains. Biol Psychiatry 42:186S

Lewin W (1960) Observations on selective leucotomy. J Neurol Neurosurg Psychiatry 24:37-44

Lieberman JA, Koreen AR (1993) Neurochemistry and neuroendocrinology of schizophrenia: a selective review. Schizophr Bull 19:371-429

Lodge D, Aram JA, Church J, Davies SN, Martin D, O'Shaughnessy CT, Zeman S (1987) Excitatory amino acids and phencyclidine-like drugs. In: Hicks TP, Lodge D, McLennan H (eds) Excitatory amino acid transmission. Alan R. Liss Inc, New York $\mathrm{p} 83$

Luby ED, Cohen BD, Rosenbaum G, Gottlieb JS, Kelley R (1959) Study of a new schizophrenicomimetic drug, Sernyl. Arch Neurol Psychiatry 81:363-9

Lund JS, Lund RD, Hendrickson AE, Bunt AH, Fuchs AF (1975) The origin of efferent pathways from the primary visual cortex, area 17, of the macaque monkey as shown by retrograde transport of horseradish peroxidase. J Comp Neurol 164:287303

Meltzer HY (1991) The mechanism of action of novel antipsychotic drugs. Schizophr Bull 17:263-287

Mirra SS, Heyman A, McKeel D, Sumi SM, Crain BJ, Brownlee LM, Vogel FS, Hughes JP, van Bell G (1991) The consortium to establish a registry for Alzheimer's disease (CERAD). Part II. Standardisation of the neuropathologic assessment of Alzheimer's disease. Neurology 41:479-486

Morris RGM, Anderson E, Lynch GS, Baudry M (1986) Selective impairment of learning and blockade of long-term potentiation by an $N$-methyl-D-aspartate receptor antagonist, AP5. Nature 319:774-776

Newman SJ, Gentleman SM (1997) Microwave antigen retrieval in formaldehyde-fixed human brain tissue. In: Rayne RC (eds) vol 72, Humana Press, New Jersey, pp 145-152

Nishikawa T, Takashima M, Toru M (1983) Increased $\left[{ }^{3} \mathrm{H}\right]$ kainic acid binding in the prefrontal cortex in schizophrenia. Neurosci Lett 40:245-250
Olney JW, Farber NB (1995) Glutamate receptor dysfunction and schizophrenia. Arch Gen Psychiatry 52:998-1007

Ong WY, Garey LJ (1993) Ultrastructural features of biopsied temporopolar cortex (area 38) in a case of schizophrenia. Schizophr Res 10:15-27

Ong WY, Garey LJ (1996) A light and electron microscopic study of GluR4-positive cells in human cerebral cortex. Neurosci Lett 210:107-110

Oretti RG, Spurlock G, Buckland PR, McGuffin P (1994) Lack of effect of antipsychotic and antidepressant drugs on glutamate receptor mRNA levels in rat brain. Neurosci Lett 177:39-43

Petralia RS, Wenthold RJ (1992) Light and electron immunocytochemical localization of AMPA-selective glutamate receptors in the rat brain. J Comp Neurol 318:329-354

Petralia RS, Wang YX, Wenthold RJ (1994) The NMDA receptor subunits NR2A and NR2B show histological and ultrastructural localization patterns similar to those of NR1. J Neurosci 14:6102-120

Porter RH, Eastwood SL, Harrison PJ (1997) Distribution of kainate receptor subunit mRNAs in human hippocampus, neocortex and cerebellum, and bilateral reduction of hippocampal GluR6 and KA2 transcripts in schizophrenia. Brain Res. 751:217-231

Radewicz K, Garey LJ, Gentleman SM, Reynolds R (2000) Increase in HLA-DR immunoreactive microglia in frontal and temporal cortex of chronic schizophrenics. J Neuropathol Exp Neurol 59:137-150

Rubin P, Holm S, Madsen PL, Friberg L, Videbech P, Andersen HS, Bendsen BB, Stromso N, Larsen JK, Lassen NA, Hemmingsen R (1994) Regional cerebral blood flow distribution in newly diagnosed schizophrenia and schizophreniform disorder. Psychiatry Res 53:57-75

Satoh K, Narita M, Someya T, Fukuyama H, Yonekura Y (1993) Functional brain imaging of a catatonic type of schizophrenia: PET and SPECT studies. Jap J Psychiatry Neurol 47:881-885

Selemon LD, Goldman-Rakic PS (1999) The reduced neuropil hypothesis: a circuit based model of schizophrenia. Biol Psychiatry 45:17-25

Selemon LD, Rajkowska G, Goldman-Rakic PS (1995) Abnormally high neuronal density in the schizophrenic cortex. A morphometric analysis of prefrontal area 9 and occipital area 17. Arch Gen Psychiatry 52:805-818

Shatz CJ (1990) Impulse activity and the patterning of connections during CNS development. Neuron 5:745-756

Sherman AD, Hegwood TS, Baruah S, Waziri R (1991) Deficient NMDA-mediated glutamate release from synaptosomes of schizophrenics. Biol Psychiatry 30:1191-1198

Sokolov BP (1998) Expression of NMDAR1, GluR1, GluR7, and KA1 glutamate receptor mRNAs is decreased in frontal cortex of "neuroleptic-free" schizophrenics: evidence on reversible up-regulation by typical neuroleptics. J Neurochem 71:2454 2464

Sommer H, Quandt J (1970) Langzeitbehandlung mit Chlorpromazin im Tierexperiment. Fortschr Neurol Psychiatry $38: 466-491$

Squires RF, Saederup E (1991) A review of evidence for GABergic predominance/glutamatergic deficit as a common etiological factor in both schizophrenia and affective psychoses: more support for a continuum hypothesis of 'functional' psychosis. Neurochem Res 16:1099-1111

Toru M, Watanabe S, Shibuya H et al (1988) Neurotransmitters, receptors and neuropeptides in post-mortem brains of chronic schizophrenic patients. Acta Psychiatry Scand 78:121-137

Uranova NA, Orlovskaya DD, Apel K, Klintsova AY., Haselhorst U, Schenk H (1991) Morphometric study of synaptic patterns in the rat caudate nucleus and hippocampus under haloperidol treatment. Synapse 7:253-259

Vickers JC, Huntley GW, Edwards AM, Moran T, Rogers SW, Heinemann SF, Morrison JH (1993) Quantitative localization of AMPA/kainate and kainate glutamate receptor subunit 
immunoreactivity in neurochemically identified subpopulations of neurons in the prefrontal cortex of the macaque monkey. J Neurosci 13:2982-2992

Vickers JC, Huntley GW, Hof PR, Bederson J, DeFelipe J, Morrison JH (1995) Immunocytochemical localization of nonNMDA ionotropic excitatory amino acid receptor subunits in human neocortex. Brain Res 671:175-180
Weinberger DR, Berman KF, Zec RF (1986) Physiologic dysfunction of dorsolateral prefrontal cortex in schizophrenia: I. Regional cerebral blood flow evidence. Arch Gen Psychiatry 43:114-124

Zukin SR, Zukin RS (1979) Specific $\left[{ }^{3} \mathrm{H}\right]$ phencyclidine binding in rat central nervous system. Proc Natl Acad Sci USA 76:53725376 